\section{THE PARENTAL PROCESS OF APPRAISING CHILD PAIN: AN INTERNATIONAL QUALITATIVE STUDY}

O. Gawronski ${ }^{1}$, S. Padrini ${ }^{2}$, A. Ragni ${ }^{3}$, I. Ciaralli ${ }^{4}$, I. Dall'Oglio ${ }^{1}$, E. Tiozzo ${ }^{1}$, D. Ballweg ${ }^{5}$, K. Cambern ${ }^{5}$, L. Mundy ${ }^{5}$, S. Tucker ${ }^{6}$, S. Meiers ${ }^{7}$

${ }^{1}$ Nursing Continuing Education and Research, ${ }^{2}$ Cardiac Intensive Care Unit, ${ }^{3}$ Nenatal Intensive Care Unit, ${ }^{4}$ Department of Oncology. Haemathology, Ospedale Pediatrico Bambino Gesù, Roma, Italy, ${ }^{5}$ Department of Nursing, ${ }^{6}$ Nursing Research Division, Mayo Clinic, ${ }^{7}$ College of Nursing and Health Sciences, Winona State

University-Rochester, Rochester, MN, USA

Pain is a common experience among children and infants in clinical settings worldwide. Nurses often depend upon parents to aid in assessment of pain. Yet, the unique parent's processes of appraising pain are not fully known. The purpose of this study was to explore the social process of parent appraisal of child and infant pain and to examine cultural influences upon this appraisal.

A qualitative design with grounded theory method was used to guide data collection and analysis in the larger international study. Settings were two acute care clinical sites, one in Rome, Italy and one at a large Midwestern tertiary hospital in the USA. This paper reports on findings from the Italian sample of 12 parents of children hospitalized in three units (the cardiac surgical intensive care, the neonatal intensive care unit and the oncology-emathology unit). Data were drawn from semi-structured interviews and bedside observations of parent-child interactions.

A constant comparative data analysis approach resulted in coding of text and observation data, thematic naming, comparison of differences and commonalities between participants, and reassembling of the themes. The core process of parent appraisal of pain was identified as "struggling to understand the hurdle of pain while protecting the child" Parents described a process of comparing, observing, grading, and rationalizing in their struggle to understand child pain. Unique cultural values and beliefs influenced the parent's depth of involvement in the appraisal process. Parent sense of success in protecting the child was interwoven with the relationship with the provider.

\section{HYPEROXIC RESUSCITATION GIVES INCREASED OXIDATIVE STRESS IN LUNG TISSUE AND INFLUENCE THE CAPACITY TO REPAIR BASE LESIONS ON DNA}

R. Solberg ${ }^{1}$, J.H. Andresen ${ }^{1}$, G.I. Borge ${ }^{2}$, A. Ellingsen ${ }^{3}$, M. Bjørås ${ }^{3}$, O.D. Saugstad ${ }^{1}$

${ }^{1}$ Department of Paediatric Research, Oslo University Hospital, Rikshospitalet, Oslo, ${ }^{2}$ Nofirma Mat, Norwegian Food Research Institute, Ås, ${ }^{3}$ Centre for Molecular Biology and Neuroscience, Institute of Medical Microbiology, Oslo University Hospital, Rikshospitalet, Oslo, Norway

Background/aims: Newborn resuscitation with pure oxygen may induce short- and long term pathological changes via oxidative stress. Oxygen can adversely affect all tissues of the body. We studied DNA repair activities in lung-, liver- and brain tissue 9 hours(h) after preceding hypoxia and reoxygenation. In lung tissue antioxidant capacity and DNA repair activity was assessed at both 1 and $9 \mathrm{~h}$.

Methods: Hypoxemia was induced by ventilation of $8 \% \mathrm{O}_{2}$ in $\mathrm{N}_{2}$ and maintained until Base Excess reached $-20 \mathrm{mmol} / \mathrm{L}$ or mean arterial blood pressure decreased below $15 \mathrm{mmHg}$. The piglets, $n=5-10$ in each group, were resuscitated for 15 or $30 \mathrm{~min}$ by ventilation with 21 or $100 \% \mathrm{O}_{2}$ and observed for 1 or $9 \mathrm{~h}$ before lung-, liver and brain tissue samples were removed and snap-frozen. Controls went through surgery, stabilization and ventilation, but were not exposed to hypoxia and reoxygenation.

Results: One hour after end of resuscitation the total antioxidant capacity in lung tissue was significant lower in the group resuscitated with $100 \% \mathrm{O}_{2}$ compared to $21 \%(\mathrm{p}<0.02)$, but after $9 \mathrm{~h}$ there were no difference. The DNA repair activity was significantly reduced $1 \mathrm{~h}$ after resuscitation; in the $100 \%$ group $55 \%$ reduction vs controls $(p=0.008)$ and $28 \%$ vs room air $(p=0.047)$. After $9 \mathrm{~h}$ there was still a tendency to reduced base lesion repair on DNA in tissue from the lung and prefrontal cortex.

Conclusions: Hypoxiaandsubsequentresuscitation with $100 \% \mathrm{O}_{2}$ causes increased oxidative stress and risk of cell damage and long term consequences such as accumulation of mutations in the genome. 